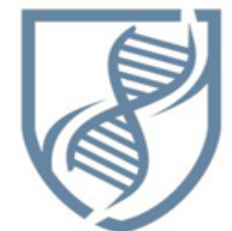

Journal of Bioscience and Applied Research

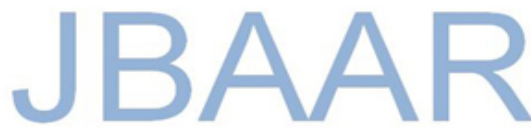

WWW.JBAAR.ORG

\title{
Efficacy of saffron extract and fenugreek seeds supplementation on liver of streptozotocin induced diabetic rats
}

Doaa A. Ali, Hanaa Serag, Ahmed Abdeen and Radwa Refaat.

Zoology Department - Faculty of Science - Mansoura University, Mansoura, Egypt.

( Corresponding author email: doaasakr@mans.edu.eg)

\begin{abstract}
The present study aimed to investigate the possible hypoglycemic and hepatoprotective effects of saffron extract $(100 \mathrm{mg} / \mathrm{kg}$ b.wt) and fenugreek supplementation (1.4 g/day/kg b.wt) in STZ- induced diabetic rats at biochemical, histological, histochemical and ultrastructural levels. The results indicated that a single dose of STZ (50 $\mathrm{mg} / \mathrm{kg}$ b wt, i.p) caused a significant increase in serum and liver total lipids, total cholesterol and triglyceride as well as serum low density and a very low density lipoprotein, accompanied by an increase in serum glucose level and oxidative stress marker, malondialdehyde and hydrogen peroxide level as well as serum aspartate and alanine aminotransferase activities. The results also reported a significant decrease in the high density lipoprotein, serum and liver total protein, serum albumin and globulin contents and $\mathrm{A} / \mathrm{G}$ ratio, as well as a significant decrease in serum insulin level and the liver enzyme activities and the hepatic glutathione content. Histologically, STZ treated group showed degenerative changes in the pancreas and alteration in the structural integrity of the hepatocytes and their intracellular organelles. Histochemically, liver sections of STZ treated animals displayed marked decrease in the glycogen and total protein contents. On the other hand, the intake of saffron or fenugreek minimize the disturbance observed in the most tested parameters resulted from STZ administration and improve the liver structure and functions. Finally, it can be concluded that the intake of natural product such as saffron or fenugreek may be effective in reducing the diabetic liver injury induced by streptozotocin and the fenugreek supplementation showed more amelioration than saffron extract.
\end{abstract}

Keywords: Fenugreek, Histochemistry, Histopathology, Liver, Saffron, Streptozotocin, Ultrastructure

\section{Introduction}

Diabetes mellitus (DM) is a chronic metabolic disorder with numerous complications. The number of people suffering from diabetes worldwide is increasing at an alarming rate. It is predicated that about 366 million people are likely to be diabetic by the year 2030 (Oyedemi et al., 2011). Streptozotocin is mainly used to induce the experimental insulin-dependent diabetes which is usually accompanied with many clinical and metabolic disturbances (Montero et al., 2000). The liver is insulin-dependent tissue that plays a vital role in glucose and lipid homeostasis and is severely affected in diabetes disease as it recognized as major complications of diabetes (Sivajothi et al., 2007). Herbal medicines are being increasingly utilized in developed countries to treat a wide variety of clinical disease. Herbal remedies are considered to be effective and safe alternative in the management of treatment for diabetes mellitus and its complications (Heeba and Abd-Elghany, 2010).

Saffron (dried stigmas of the flowers of Crocus sativus L) is the world's most expensive spice belongs to the Iridaceae family (Zargari, 1993). Saffron has been traditionally used as an antispasmodic, eupeptic, gingival sedative and emmenagogue (Schmidt et al., 2007 and Kataria et al., 2011). Crocin, crocetin and Safranal are the major active constituents of saffron (Liakopoulou-Kyriakides and Kyriakidis, 2002). Previous studies have demonstrated that saffron and its active constituents have a wide variety of pharmacological effects such as antioxidant (Assimopoulou et al., 2005 and Chen et al., 2008). Antitumor (Chermahini et al., 2010), anti-genotoxic, 
memory and learning enhancing (Abe and Saito, 2000 and Tamaddonfard et al., 2013), neuroprotective, analgesic and anti-inflammatory, anti-convulsant, antianxiety, antidepressant, anti-hypertensive (Razavi et al., 2013), and anti-hyperlipidemic effects (Srivastava et al., 2010, Bathaie and Mousavi, 2010 and Kataria et al., 2011). Also, crocetin has increased insulin sensitivity and ameliorated abnormalities related to insulin resistance such as impaired glucose tolerance, hyperinsulinemia, dyslipidemia and hypertension due to high- fructose diet and dexamethasone injection in rats (Xi et al., 2005;2007). Oxidative stress can cause insulin resistance and the long-term complications of diabetes; antioxidants may be very important in mitigating impaired insulin secretion and action in insulin resistance and prevent diabetes complications (Rahimi et al., 2005 and Evans, 2007).

Fenugreek (Trigonella foenum-graecum) is an annual herb belonging to family Leguminosae and is one of the oldest herbs known originating in the Mediterranean region and Asia (Azaizeh et al., 2006). Fenugreek seeds have been traditionally used in the treatment of gastrointestinal disorders, gout, wound healing, inflammation, hyperlipidemia, and diabetes (Miraldi et al., 2001; Basch et al., 2003 and WHO, 2004). Fenugreek have also been reported to exhibit pharmacological properties such as antitumor, antiviral, antimicrobial, anti-inflammatory, hypotensive and antioxidant (Cowan, 1999; Amin et al., 2005; Abou El-Soud et al., 2007 and Kassaian et al., 2009). T. F. graecum seeds contain lysine and Ltryptophan rich proteins, mucilaginous fiber and other rare chemical constituents such as saponins, coumarin, fenugreekine, nicotinic acid , sapogenins, phytic acid, scopoletin and trigonelline, which are thought to account for many of its presumed therapeutic effects (Billaud, 2001; Basch et al., 2003 and Puri et al., 2012)

The present study aimed to investigate the possible hypoglycemic and hepatoprotective properties of saffron extract and fenugreek supplementation in diabetic liver induced by STZ in rats at biochemical, histological, histochemical and ultrastructural levels.

\section{Materials and Methods}

Streptozotecin (STZ) was purchased from Sigma Company (USA). It was applied as a single freshly prepared dose (50mg/kg body weight), dissolved in citrate buffer at $\mathrm{pH} 4.4$, as previously recommended by Nandini et al. (2000).

\section{Preparation of Saffron extract}

An aqueous extract of saffron (Crocus sativus L) was prepared using (1g) dried stigmas powder of saffron, which were soaked in $100 \mathrm{ml}$ of double distilled water for one hour and homogenized. The homogenate was centrifuge at $2000 \mathrm{rpm}$ for $10 \mathrm{~min}$ to remove the particles and supernatant was used for the experiment. The animals received a daily dose of saffron extract $(100 \mathrm{mg} / \mathrm{kg} \quad$ b.wt) for 6 weeks according to Premkumar et al. (2003).

\section{Fenugreek supplementation}

Fenugreek seed (Trigonella foenum-graecum) powder was given in the diet in a dose ( $20 \mathrm{~g} / \mathrm{kg}$ diet) for 6 weeks according to Mitra and Bhattacharya (2006).

\section{Experimental design}

The study was performed on male Wistar albino rats (Rattus rattus), weighing 120-140 g. Rats were housed in stainless steel cages at a well-ventilated animal house in a temperature-controlled room at 22$25^{\circ} \mathrm{C}$, maintained under specific pathogen-free conditions on a $12 \mathrm{hr}$ light/dark cycle at the animal house lab., Faculty of Science, Mansoura University, Mansoura, Egypt. They were acclimated to laboratory conditions for 2 weeks prior to experiment; rats were permitted adequate standard diet and given water ad labium. All experiments were carried out in accordance with the protocols approved by the Local Experimental Animal Ethics Committee. After the adaptation period, rats were randomly divided into six groups 10 rats each.

Group 1; The control group. Rats of this group were received a standard diet (SD) which composed of casein $15.0 \%$, starch, $67.0 \%$, corn oil $8.0 \%$, salt mixture $4.0 \%$, vitamin mixture $1.0 \%$ and wood fiber $5.0 \%$ for 6 weeks (Ulloa et al., 1988) and interperitoneal injected with a single dose of citrate buffer at PH 4.4 (50 mg $/ \mathrm{kg}$ body weight) (Nandini et al., 2000). Group 2; Saffron treated group: Rats of this group were received SD with daily oral administration of an aqueous extract of saffron (100mg/ kg b.wt) for 6 weeks (Premkumar et al., 2003). Group 3; Fenugreek treated group: Rats of this group were fed diet supplemented with fenugreek powder daily for 6 weeks (Mitra and Bhattacharya, 2006). Group 4; Diabetic group: Rats were interperitoneally injected with a single dose of streptozotocin (50 mg $/ \mathrm{kg} \mathrm{b} \mathrm{wt)}$ after 4 week (Nandini et al., 2000). Group 5; Saffron+ Diabetic group: Rats of this group were received saffron as described in group 2 for 6 weeks, in the same time the animals were interperitoneally 
injected with a single dose of streptozotocin (50 mg / kg bwt). Group 6; Fenugreek+ Diabetic group: Rats of this group were fed diet supplemented with fenugreek powder as described in group 3 for 6 weeks, and interperitoneally injected with a single dose of streptozotocin (50 mg / kg b wt).

\section{Blood sampling and biochemical investigations:}

At the end of the experimental period (6 weeks), all rats were fasted overnight and sacrificed under ether anesthesia. From each rat, a blood sample was collected into clean centrifuge tube and allowed to clot, then centrifuged at 3000 r.p.m for 10 minutes at $4^{\circ} \mathrm{C}$ for biochemical analysis. Immediately after collecting blood, the rats were dissected and three part of the liver from each rat were removed, the first one was accurately weighed and homogenized using homogenizer in a $10 \%$ fold volume of bidistilled water , the homogenate was kept frozen at $-20^{\circ} \mathrm{C}$ until being analyzed, the second part of the liver and a part of the pancreas placed into $10 \%$ buffered neutral formalin for histological and histochemical studies, the third part of the liver fixed in 4F1G (pH 7.4), for transmission electron microscopic investigation.

\section{Serum glucose and insulin assay:}

Serum glucose level was determined using colorimetric kit according to the method of McCleary and Codd (1991), and serum insulin level was measured by enzyme linked immunosorbant assay (ELISA) kit according to the method of Flier et al (1976).

\section{Lipids profile assay:}

Total lipids level was estimated according to Frings et al (1972), total cholesterol, triglycerides level, and the level of serum HDL-C was estimated by colorimetric method of Young (1995), using HDL-C kit and the LDL-C and vLDL-C levels in serum were calculated according to equations described by Friedewald et al. (1972).

\section{Protein profile:}

Total protein content was estimated by colorimetric method according to the method of Henry (1964), total albumin was estimated in serum using diamond diagnostics kit according to Doumas et al. (1971) and globulin contents and A/G ratio were calculated.

\section{Liver functions:}

Serum and liver alanine aminotransferase (ALT) and aspartate aminotransferase (AST) activities were determined using colorimetric method according to the technique of Reitman and Frankel (1957).Malonedialdehyde (MDA) content was determined according to the method of Ohkawa et al. (1979). Glutathione (GSH) content was determined according to the method described by Prins and Loose (1969). Hydrogen peroxide content was determined using colorimetric method of Aebi (1984).

\section{Histological examination}

The fixed liver and pancreas specimens were dehydrated in ascending series of ethyl alcohol and embedded in paraffin. Sections at $5 \mu \mathrm{m}$ thickness were stained according to the following histological stains: H\&E (Weesner, 1968) and Masson's Trichrome method (Masson, 1929) for collagen fibres.

\section{Histochemical investigation}

Total polysaccharides were detected using Periodic Acid Schiff's (PAS) reaction (Pearse, 1985). Also, the total protein was detected using mercurybromophenol blue stain (Mazia et al., 1953).

\section{Electron microscopic investigation}

Dissected liver samples were fixed in 4F1G in phosphate buffer (pH 7.2) at $4^{\circ} \mathrm{C}$ and post-fixed in $1 \%$ cold osmium tetroxide in phosphate buffer at $\mathrm{pH} 7.2$ for three hours. The specimens were then dehydrated in graded ethanol and embedded in Epson-Araldite resin. Ultrathin sections were stained by uranyl acetate followed by lead citrate as described by Reynolds (1963) and examined on Joel Electron Microscope (JAPAN) operating at $60 \mathrm{kV}$.

\section{Statistical analysis}

Data were analyzed statistically using Student's $t$ test using SPSS software and the data were presented as mean \pm SEM. Differences with $\mathrm{p} \leq 0.05$ were considered significant.

\section{Results}

\section{Biochemical results}

The obtained data in the present study are represented in Tables 1, 2 and 3. Table(1) showed that a single intraperitoneal dose of streptozotocin $(50 \mathrm{mg}$ $/ \mathrm{kg} \mathrm{b}$ wt ) resulted in alterations in comparison with the control group including significant increases in serum and liver total lipids, total cholesterol and triglyceride as well as serum low density and a very low density lipoprotein but the decrement was reported in the high density lipoprotein. Meanwhile the intake of saffron or fenugreek ameliorated the above mentioned parameters. As shown in Table (2), 
streptozotocin treated rats represented significant glutathione content, and serum and liver alanine decrease in serum and liver total protein, serum aminotransferase and aspartate aminotransferase albumin and globulin contents and $\mathrm{A} / \mathrm{G}$ ratio activities in different rat groups. Significant increase accompanied by a significant decrease in serum in oxidative stress parameters, MDA and $\mathrm{H}_{2} \mathrm{O}_{2}$ as well insulin level in contrast to a significant increase in as the serum AST and ALT enzyme activities with serum glucose level. However, supplementation of significant decrease in the antioxidant parameter, diabetic rats with saffron or fenugreek significantly GSH content accompanied with the decrease in the improved the reduction in the above parameters, with AST and ALT activities in the liver of diabetic rat the decrease in the serum glucose level; the group were noticed when compared to the control improvement was more pronounced in the group group. On the other hand, the administration with administered with fenugreek more than that treated saffron or fenugreek, improved both the serum and with saffron. Table (3) represented the liver liver enzymatic activities and the oxidative and malondialdehyde, hydrogen peroxide level and antioxidant parameters.

Table (1): Effects of saffron extract and fenugreek seeds on Serum and liver lipid profile in streptozotocin induced diabetic rats

\begin{tabular}{|c|c|c|c|c|c|c|c|}
\hline \multicolumn{2}{|c|}{ Groups } & Control & \multirow{2}{*}{\begin{tabular}{|l|} 
Saffron \\
$520 \pm 3.9$
\end{tabular}} & \multirow{2}{*}{$\begin{array}{c}\text { Fenugreek } \\
517 \pm 5.5\end{array}$} & \multirow{2}{*}{\begin{tabular}{|l|} 
Diabetic \\
$781 \pm 9.9^{\mathrm{a}}$ \\
\end{tabular}} & \multirow{2}{*}{$\begin{array}{c}\text { Saffron +Diabetic } \\
613 \pm 7.2^{\mathrm{ab}}\end{array}$} & \multirow{2}{*}{$\begin{array}{c}\text { Fenugreek + Diabetic } \\
611 \pm 4.9^{\mathrm{ab}}\end{array}$} \\
\hline \multirow{6}{*}{ 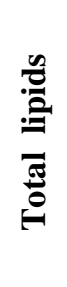 } & \multirow{3}{*}{ 春 } & $521 \pm 5.8$ & & & & & \\
\hline & & $*$ & -0.2 & -0.8 & 50.2 & 17.6 & 17.1 \\
\hline & & $* *$ & & & & -21.6 & -21.9 \\
\hline & \multirow{3}{*}{ 离 } & $65.3 \pm 3.1$ & $65.8 \pm 2.7$ & $64.0 \pm 3.2$ & $88.1 \pm 3.5^{\mathrm{a}}$ & $73.8 \pm 3.3^{\mathrm{ab}}$ & $71.6 \pm 2.3^{\mathrm{ab}}$ \\
\hline & & * & 0.8 & -1.9 & 35.5 & 13.0 & 9.2 \\
\hline & & $* *$ & & & & $\begin{array}{l}-16.1 \\
\end{array}$ & -18.7 \\
\hline \multirow{6}{*}{ 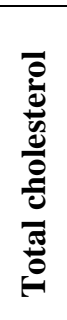 } & \multirow{3}{*}{ 焉 } & $92.5 \pm 3.0$ & $80.7 \pm 3.1^{\mathrm{a}}$ & $89.4 \pm 3.4$ & $131.5 \pm 2.6^{\mathrm{a}}$ & $102.0 \pm 3.8^{a b}$ & $110.1 \pm 4.1^{\mathrm{ab}}$ \\
\hline & & * & -12.7 & $\begin{array}{l}-3.3 \\
\end{array}$ & 42.2 & 10.2 & 18.9 \\
\hline & & \begin{tabular}{l|l}
$* *$ & \\
\end{tabular} & & & & -22.4 & -16.4 \\
\hline & \multirow{3}{*}{ 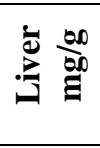 } & $14.4 \pm 0.9$ & $14.0 \pm 0.7$ & $15.1 \pm 0.8$ & $23.2 \pm 0.9^{\mathrm{a}}$ & $18.6 \pm 0.5^{\mathrm{ab}}$ & $19.2 \pm 0.5^{\mathrm{ab}}$ \\
\hline & & \begin{tabular}{l|l}
$*$ & \\
\end{tabular} & -2.8 & 4.8 & 60.4 & 29.0 & 33.0 \\
\hline & & \begin{tabular}{l|l}
$* *$ & \\
\end{tabular} & & & & -19.4 & -16.8 \\
\hline \multirow{6}{*}{ 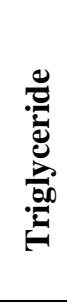 } & \multirow{3}{*}{ 奉 } & $83.2 \pm 2.3$ & $77.6 \pm 3.4$ & $87.0 \pm 3.1$ & $179.0 \pm 3.3^{\mathrm{a}}$ & $105.6 \pm 2.6^{\mathrm{ab}}$ & $112.1 \pm 3.1^{\mathrm{ab}}$ \\
\hline & & \begin{tabular}{l|l}
$*$ &
\end{tabular} & -6.5 & 4.5 & 115.0 & 26.9 & 35.0 \\
\hline & & $* *$ & & & & -41.2 & -37.1 \\
\hline & \multirow{3}{*}{ : } & $13.1 \pm 0.8$ & $12.5 \pm 0.9$ & $13.6 \pm 0.6$ & $28.8 \pm 0.9^{\mathrm{a}}$ & $15.8 \pm 0.9^{\mathrm{ab}}$ & $19.5 \pm 0.8^{\text {ab }}$ \\
\hline & & * & -4.5 & 4.6 & 121.5 & 21.5 & 50.1 \\
\hline & & $* *$ & & & & -45.1 & -32.3 \\
\hline \multirow{9}{*}{ స్ } & \multirow{3}{*}{ 岁 } & $44.0 \pm 2.3$ & $46.5 \pm 1.4$ & $45.0 \pm 1.8$ & $23.0 \pm 0.8^{\mathrm{a}}$ & $30.1 \pm 1.2^{\text {ab }}$ & $28.8 \pm 1.1^{\text {ab }}$ \\
\hline & & $*$ & 5.6 & 2.2 & -48.0 & -31.0 & -34.5 \\
\hline & & \begin{tabular}{|l|l}
$* *$ & \\
\end{tabular} & & & & 30.4 & 25.2 \\
\hline & \multirow{3}{*}{ 岂 } & $33.5 \pm 0.7$ & $30.1 \pm 0.8^{\mathrm{a}}$ & $32.3 \pm 0.9$ & $71.5 \pm 1.9^{\mathrm{a}}$ & $51.0 \pm 1.4^{\mathrm{ab}}$ & $60.7 \pm 1.7^{\text {ab }}$ \\
\hline & & $*$ & -10.1 & -3.6 & 112.9 & 52.2 & 80.1 \\
\hline & & $* *$ & & & & -28.0 & -15.5 \\
\hline & \multirow{3}{*}{ 毫 } & $16.2 \pm 0.6$ & $15.2 \pm 0.7$ & $15.5 \pm 0.5$ & $35.7 \pm 0.8^{\mathrm{a}}$ & $22.2 \pm 0.6^{\mathrm{ab}}$ & $24.4 \pm 0.6^{\mathrm{ab}}$ \\
\hline & & * & -6.1 & $\begin{array}{l}-4.3 \\
\end{array}$ & 120.0 & 37.0 & 50.6 \\
\hline & & $* *$ & & & & -37.8 & $\begin{array}{l}-31.6 \\
\end{array}$ \\
\hline
\end{tabular}

Data are presented as means $\pm \mathrm{SE}$ ( $\mathrm{n}=6$ for each group).

a Significant change at $\mathrm{p} \leq 0.05$ comparing with control group, $b$ Significant change at $\mathrm{p} \leq 0.05$ comparing with diabetic group

* \% of change compared to control group \& ** \% of change compared to diabetic group 
Table (2): Effects of saffron extract and fenugreek seeds on serum and liver total proteins content, serum albumin, globulin, $\mathrm{A} / \mathrm{G}$ ratio, glucose and insulin level in streptozotocin induced diabetic rats.

\begin{tabular}{|c|c|c|c|c|c|c|c|}
\hline \multicolumn{2}{|c|}{ Parameters } & Control & Saffron & Fenugreek & Diabetic & Saffron +Diabetic & $\begin{array}{c}\text { Fenugreek + } \\
\text { Diabetic }\end{array}$ \\
\hline \multirow{6}{*}{ 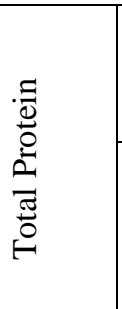 } & \multirow{3}{*}{ 急 } & $7.61 \pm 0.22$ & $7.42 \pm 0.27$ & $7.33 \pm 0.15$ & $4.91 \pm 0.14^{\mathrm{a}}$ & $5.89 \pm 0.16^{\mathrm{ab}}$ & $6.30 \pm 0.17^{\text {ab }}$ \\
\hline & & \begin{tabular}{l|l}
$*$ & \\
\end{tabular} & -2.4 & -3.6 & -35.5 & -22.6 & -17.2 \\
\hline & & $* *$ & & & & 19.9 & 28.3 \\
\hline & \multirow{3}{*}{ 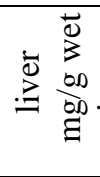 } & $1.40 \pm 0.06$ & $1.33 \pm 0.06$ & $1.31 \pm 0.07$ & $0.48 \pm 0.04^{\mathrm{a}}$ & $0.74 \pm 0.03^{\text {ab }}$ & $0.88 \pm 0.04^{\mathrm{ab}}$ \\
\hline & & * & -5.0 & -7.1 & -65.5 & -42.0 & -32.0 \\
\hline & & $* *$ & & & & 50.0 & 76.0 \\
\hline \multirow{6}{*}{ 書 } & \multirow{3}{*}{ 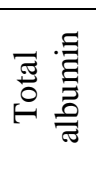 } & $4.4 \pm 0.12$ & $4.22 \pm 0.09$ & $4.13 \pm 0.10$ & $2.45 \pm 0.11^{\mathrm{a}}$ & $3.18 \pm 0.09^{a b}$ & $3.33 \pm 0.12^{\mathrm{ab}}$ \\
\hline & & * & -4.1 & -6.1 & -44.3 & -27.7 & -25.0 \\
\hline & & \begin{tabular}{l|l}
$* *$ &
\end{tabular} & & & & 29.8 & 35.9 \\
\hline & \multirow{3}{*}{ 퓸유 } & $3.21 \pm 0.03$ & $3.2 \pm 0.10$ & $3.2 \pm 0.08$ & $2.46 \pm 0.05^{\mathrm{a}}$ & $2.71 \pm 0.06^{\mathrm{ab}}$ & $2.97 \pm 0.10^{\text {ab }}$ \\
\hline & & * & -0.3 & -0.3 & -23.4 & -15.6 & -7.5 \\
\hline & & $* *$ & & & & 10.2 & 20.7 \\
\hline \multirow{3}{*}{ 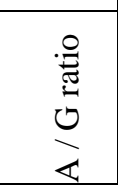 } & & $1.37 \pm 0.02$ & $1.31 \pm 0.03$ & $1.29 \pm 0.01$ & $0.99 \pm 0.04^{\mathrm{a}}$ & $1.17 \pm 0.05^{\mathrm{ab}}$ & $1.12 \pm 0.02^{\mathrm{ab}}$ \\
\hline & & $*$ & -4.8 & -5.8 & -27.7 & $\begin{array}{ll}-14.6 \\
\end{array}$ & -18.2 \\
\hline & & $* *$ & & & & 18.1 & 13.1 \\
\hline \multirow{3}{*}{ 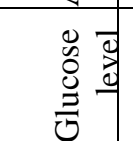 } & \multirow{3}{*}{ 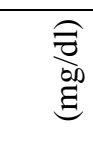 } & $89.3 \pm 4.2$ & $91.2 \pm 5.0$ & $90.1 \pm 6.8$ & $258.0 \pm 11^{\mathrm{a}}$ & $162.2 \pm 7.2^{\mathrm{ab}}$ & $143.3 \pm 6.1^{\text {ab }}$ \\
\hline & & \begin{tabular}{l|l}
$*$ & \\
\end{tabular} & 2.1 & 0.7 & 189.0 & 82.0 & 60.7 \\
\hline & & $* *$ & & & & -37.0 & -44.6 \\
\hline \multirow{3}{*}{ 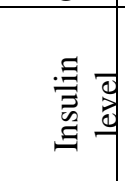 } & \multirow{3}{*}{ 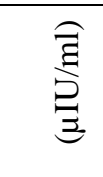 } & $3.4 \pm 0.58$ & $3.5 \pm 0.14$ & $3.24 \pm 0.19$ & $1.03 \pm 0.07^{\mathrm{a}}$ & $1.96 \pm 0.09^{\mathrm{ab}}$ & $2.1 \pm 0.07^{\mathrm{ab}}$ \\
\hline & & * & 2.9 & -4.7 & -69.7 & -42.5 & -38.2 \\
\hline & & $* *$ & & & & 90.0 & 103.0 \\
\hline
\end{tabular}

Data are presented as means $\pm \mathrm{SE}$ ( $\mathrm{n}=6$ for each group).

a Significant change at $\mathrm{p} \leq 0.05$ on comparing with control group

b Significant change at $\mathrm{p} \leq 0.05$ on comparing with diabetic group

* \% of change compared to control group \& ** \% of change compared to diabetic group

\section{Histological observations.}

Histological examination of the pancreas: Pancreatic tissue of the control group showed normal pancreatic structure. The pale stained islets of langerhans "the endocrine component" were scattered throughout the exocrine component with well define boundary. The islets are made up of irregular cords or masses of polygonal epithelial cells (Fig 1A). Pancreatic sections of animals treated with either saffron or fenugreek showed normal pancreatic architecture with no observable pathological finding in the cells of islets of langerhans (Figs 1B\&1C). On the other hand, pancreas section of STZ-treated group showed degenerative changes in islets of langerhans, homogenization of the center and apparent relative reduction in the size and number of islets. Some of the islet cells showed vacuolated cytoplasm with nuclear changes as karyolysis, disappearing of nucleus as well as residue of destructed cells was observed (Fig 1D). In other foci, irregular outline of the islet and an increased in reticent septa were noticed (Fig 1E). However, histological examination of pancreatic tissue of saffron or fenugreek + STZ induced diabetic rat showed improvement in the islet structure and restoration of normal pancreatic architecture (Figs $1 F \& 1 G)$. 
Table (3): Effects of saffron extract and fenugreek seeds on liver malondialdehyde content, hydrogen peroxide level, glutathione content, serum and liver alanine aminotransferase and aspartate aminotransferase in streptozotocin induced diabetic rats.

\begin{tabular}{|c|c|c|c|c|c|c|c|}
\hline \multirow{2}{*}{\multicolumn{2}{|c|}{ Groups }} & Control & Saffron & Fenugreek & Diabetic & Saffron +Diabetic & Fenugreek + Diabetic \\
\hline & & & & & & & \\
\hline \multirow{9}{*}{ : } & \multirow{3}{*}{ 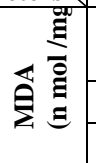 } & $84.7 \pm 2.80$ & $79.8 \pm 2.10$ & $89.0 \pm 2.90$ & $219.5 \pm 4.70^{\mathrm{a}}$ & $155.0 \pm 3.50^{\mathrm{ab}}$ & $169.0 \pm 2.80^{\mathrm{ab}}$ \\
\hline & & $*$ & -5.7 & 5.1 & 159.0 & 82.9 & 99.2 \\
\hline & & $* *$ & & & & 29.4 & 23.2 \\
\hline & \multirow{3}{*}{$\stackrel{\mathcal{N}}{N}^{N} \sum_{i}^{\dot{0}}$} & $0.15 \pm 0.01$ & $0.15 \pm 0.01$ & $0.14 \pm 0.01$ & $0.48 \pm 0.04^{\mathrm{a}}$ & $0.30 \pm 0.02^{\mathrm{ab}}$ & $0.32 \pm 0.03^{\mathrm{ab}}$ \\
\hline & & $*$ & 0.0 & -6.6 & 220.0 & 100.0 & 113.3 \\
\hline & & $* *$ & & & & -37.5 & -33.3 \\
\hline & \multirow{3}{*}{ 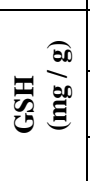 } & $3.5 \pm 0.07$ & $3.4 \pm 0.08$ & $3.6 \pm 0.09$ & $2.7 \pm 0.02^{\mathrm{a}}$ & $3.0 \pm 0.04^{\mathrm{ab}}$ & $3.1 \pm 0.07^{\mathrm{ab}}$ \\
\hline & & $*$ & -2.9 & 2.9 & -22.9 & -14.3 & -11.4 \\
\hline & & $* *$ & & & & 11.1 & 14.8 \\
\hline \multirow{6}{*}{ 占 } & \multirow{3}{*}{ 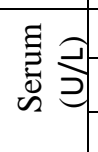 } & $33.2 \pm 0.9$ & $31.3 \pm 1.2$ & $34.6 \pm 1.1$ & $68.3 \pm 2.6^{\mathrm{a}}$ & $52.0 \pm 1.6^{\text {ab }}$ & $44.4 \pm 1.5^{\mathrm{ab}}$ \\
\hline & & $*$ & -5.7 & 4.2 & 105.7 & 56.6 & 33.7 \\
\hline & & $* *$ & & & & $\begin{array}{l}-23.6 \\
\end{array}$ & -34.9 \\
\hline & \multirow{3}{*}{ : } & $74.5 \pm 0.7$ & $77.1 \pm 1.6$ & $73.6 \pm 0.8$ & $50.8 \pm 1.2^{\mathrm{a}}$ & $63.5 \pm 1.0^{\mathrm{ab}}$ & $58.4 \pm 1.3^{a b}$ \\
\hline & & $*$ & 3.4 & -1.2 & -31.9 & -14.8 & -21.6 \\
\hline & & $* *$ & & & & 25.0 & 15.0 \\
\hline \multirow{6}{*}{ 勉 } & \multirow{3}{*}{ 国 } & $60.1 \pm 1.0$ & $54.4 \pm 1.3^{\mathrm{a}}$ & $59.2 \pm 1.5$ & $80.7 \pm 2.2^{\mathrm{a}}$ & $68.0 \pm 1.3^{\mathrm{ab}}$ & $70.2 \pm 1.1^{\text {ab }}$ \\
\hline & & $*$ & -9.5 & -1.5 & 34.2 & 13.3 & 16.6 \\
\hline & & $* *$ & & & & 15.0 & 12.5 \\
\hline & \multirow{3}{*}{ 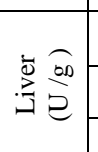 } & $139.9 \pm 1.9$ & $141.7 \pm 0.9$ & $137.3 \pm 1.5$ & $77.8 \pm 0.7^{\mathrm{a}}$ & $96.3 \pm 1.2^{\mathrm{ab}}$ & $93.2 \pm 2.0^{\mathrm{ab}}$ \\
\hline & & $*$ & 1.8 & -1.9 & 44.4 & 31.11 & 33.3 \\
\hline & & $* *$ & & & & 23.8 & 19.8 \\
\hline
\end{tabular}

Data are presented as means $\pm \mathrm{SE}$ ( $\mathrm{n}=6$ for each group).

a Significant change at $\mathrm{p} \leq 0.05$ on comparing with control group

$\mathrm{b}$ Significant change at $\mathrm{p} \leq 0.05$ on comparing with diabetic group

* \% of change compared to control group \& ** \% of change compared to diabetic group

Histological examination of the liver: The liver section of the control group showed the hepatocytes arranged in hepatic cords forming a network around the central vien (Fig 2A). Liver sections of feungreek and saffron treated groups exhibited normal architecture of the liver (Figs 2B\&2C). While liver sections of STZ-treated group displayed remarkable degenerative changes pronounced in loss of the normal liver architecture (Fig 2F) and dilation and inflammation in central and portal veins (Fig 2D). Also, in other foci, the blood sinusoids between the hepatic cells were dilated (Fig 2E). The hepatocytes appeared to be suffering from ballooning degeneration with marked cytoplasmic vacuolation fatty infiltration were observed with pyknotic and karyolitic nuclei (Figs 2D\&2F). On the other hand, liver sections of Saffron + STZ treated group exhibited some degree of improvement with minor histological changes versus the control animals pronounced in reduction in fat accumulation, less blood sinusoids dilations and less number of necrotic cells were observed. However, focal necrotic area still observed around the central vein (Fig 2G). Also, liver sections of Fenugreek + STZ treated group revealed a marked degree of recovery. The hepatic tissue showed a marked reduction in fat accumulation, absence of leucocytic infilteration, less blood sinusoids dilations and few necrotic cells (Fig 2H). 


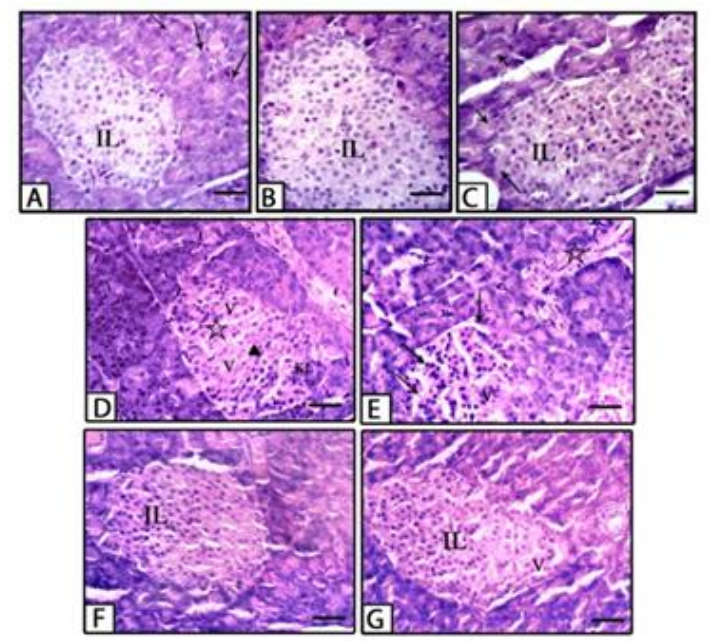

Fig (1): Pancreas histopathology of a STZ and / or saffron and fenugreek treated rats. Pancreas section of the control rats (A) showing normal structure of pancreas and the pale stained islets of Langerhans (IL) were in between the exocrine acini, pancreas sections of saffron (B) and fenugreek (C)-treated rats showing no remarkable changes, pancreas section of STZ treated rats (D\& E) demonstrating vacuolization (V) in cells of islets of Langerhans, homogenization in the center (it), irregular outline of the islet $(\rightarrow)$ and an increased the fibrous septa (FS), pancreas sections of STZ and saffron (F) or fenugreek (G)-treated rats showed improvement in the islets structure and restoration of normal pancreatic architecture (H\&E, scale bar $=50 \mu \mathrm{m})$.

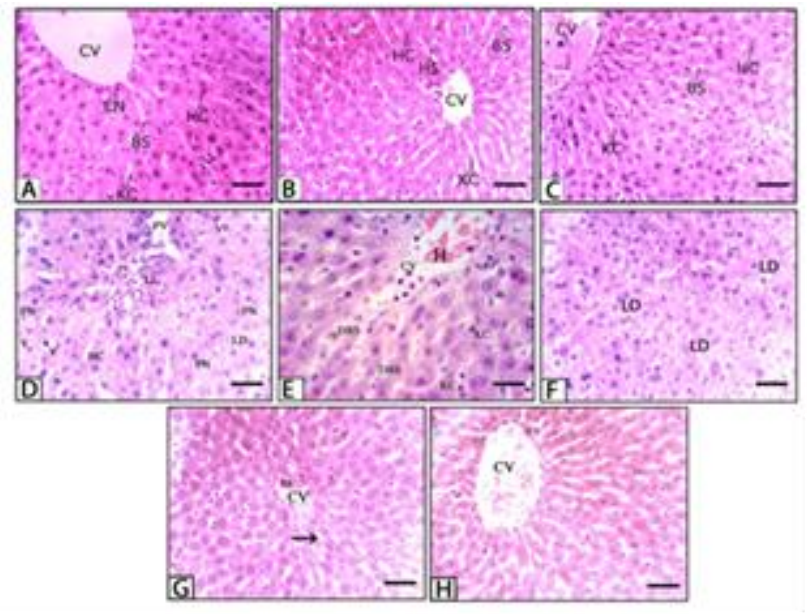

Fig (2): Liver histopathology of a STZ and/or saffron and fenugreektreated rats. Liver section of the control rats (A) showing normal hepatic architecture including central vein (CV), hepatocyets (HC) , blood sinusoids (BS) and Kupffer cells (KC), Liver sections of saffron (B) and fenugreek (C)-treated rats displaying no observable changes, liver section of STZ treated rats (D\&E\&F) showing leucocytes infiltration (LI), lipid droplets (LD), vaculization (V), pyknotic nuclei (PN), dilations in blood sinusoids (DBS) and hemorrhage (H) in central vein (CV), liver section of saffron+ STZ treated rats (G) displaying an improvement in the structure with minor pathological changes and focal necrotic area $(\rightarrow)$ around the central vein $(\mathrm{CV})$, liver section of fenugreek + STZ -treated rats $(\mathrm{H})$ showing a marked degree of recovery $(\mathrm{H} \& \mathrm{E}$, scale bar $=50 \mu \mathrm{m})$.

\section{Collagen Fibers}

Liver sections of control and saffron and fenugreek treated animals showed negligible amount of collagen fibers around the central vein (Figs 3A3C). Liver section of STZ- induced diabetic animals illustrated an increase in the amount of collagen fibers around the central vein (Fig 3D). Meanwhile, liver sections of animals treated with saffron + STZ showed negligible amount of collagen fibers around the central vein (Fig 3E). Also, examination of liver sections of animals treated with fenugreek + STZ showed small amount of collagen fibers around the central vein compared to that of STZ- induced diabetic animals (Fig 3F).

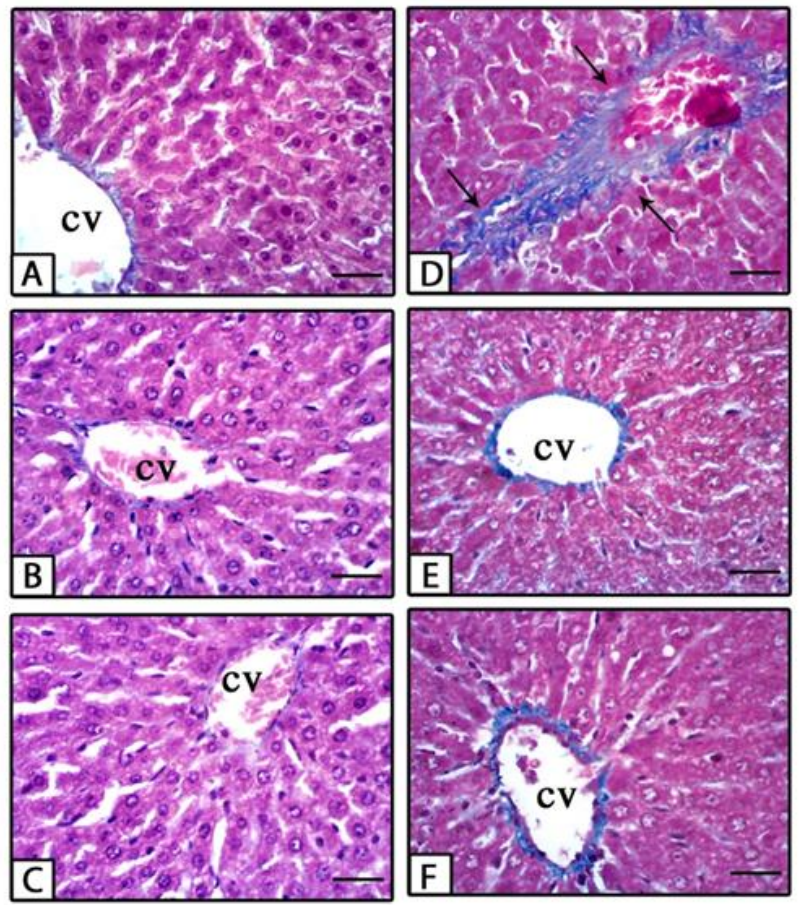

Fig (3): Liver histology of a STZ and/or saffron and fenugreek-treated rats demonstrating the collagen fibers. Liver section of control rats (A) demonstrating negligible amount of collagen fibers around the central vein (CV), liver sections of saffron (B) and fenugreek (C)-treated rats showing no observable changes, liver section of STZ treated rats (D) demonstrating large amount of collagen fibers around the central vein $(\mathrm{CV})$, both liver sections of saffron+ STZ (E) and fenugreek + STZ (F) treated rats showing small amount of collagen fibers around the central vein $(\mathrm{CV})$, (Masson trichrome stain, scale bar $=50 \mu \mathrm{m}$ ).

\section{Histochemical observations.}

Total polysaccharides: Total polysaccharides in the hepatocytes of control animals appeared in the form of deeply stained reddish granules as shown by their strong PAS positive reaction (Fig 4A). Both Saffron and fenugreek-treated animals displayed no difference 

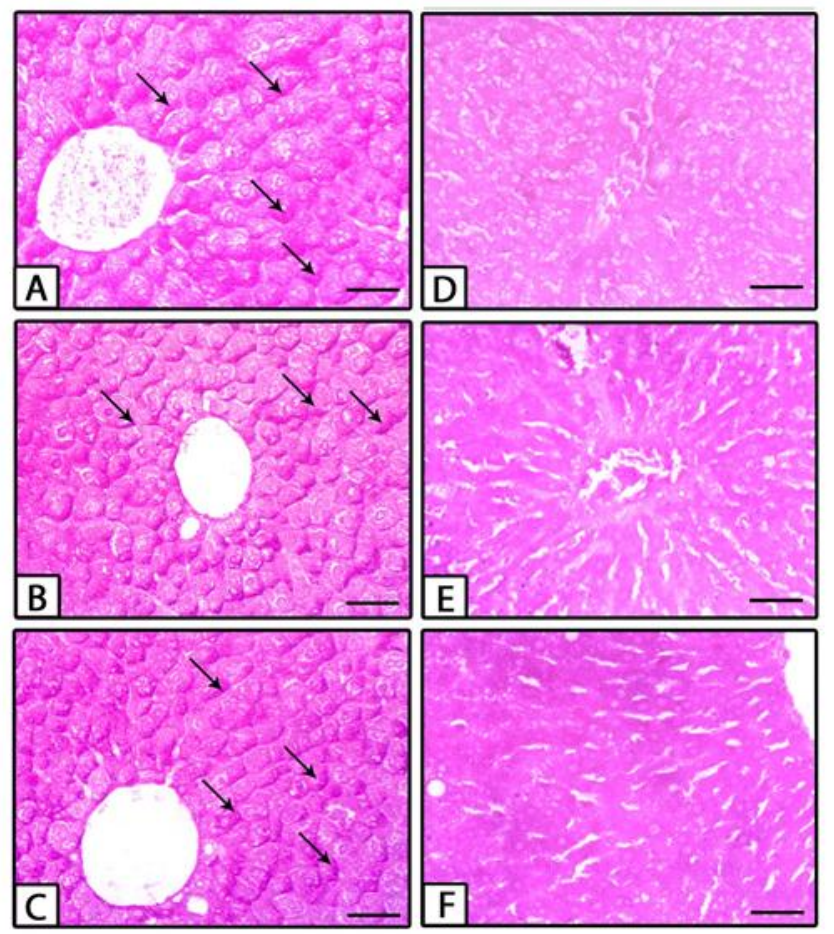

Fig (4): Liver histochemical demonstration for total polysaccharides of STZ and/or saffron and fenugreek -treated rats. Liver section of control rats (A) showing normal distribution of total polysaccharides with the glycogen flight phenomenon $(\rightarrow)$, liver sections of saffron $(B)$ and fenugreek (C) -treated rats showing strong PAS positive reaction with normal distribution of total polysaccharides, liver section of STZ treated rats (D) displaying a marked decrease in total polysaccharides, liver section of saffron+ STZ treated rats (E) demonstrating a slight decrease in total polysaccharides in the hepatocytes, liver section of fenugreek + STZ (F) -treated rats illustrating restoration of total polysaccharides content in the hepatocytes (PAS reaction, scale bar $=50 \mu \mathrm{m}$ )

in their polysaccharides contents in comparison with control group (Figs 4B\&4C). In liver section of STZinduced diabetic animals, the polysaccharides contents has been diminished in the hepatocytes and most of the cells appeared with cytoplasmic vacuolization (Fig 4D). Examination of liver sections of animals treated either with saffron+STZ or fenugreek + STZ showed improvement in polysaccharides content when compared with STZinduced diabetic animals (Figs 4E\&4F).

Total protein: The proteins in liver cells of a control rats appeared in the form of small bluish irregular particles against a weakly to moderately stained ground cytoplasm (Fig 5A). Normal distribution and contents of the proteins materials were observed in the liver tissues of either saffron or fenugreek treated groups (Figs 5B\&5C). Liver section of STZ-induced diabetic animals revealed cytoplasmic vacuolization in a large number of hepatocytes and the proteins remnants were less reactive with bromophenol blue than before (Fig 5D). Liver sections of saffron + STZ
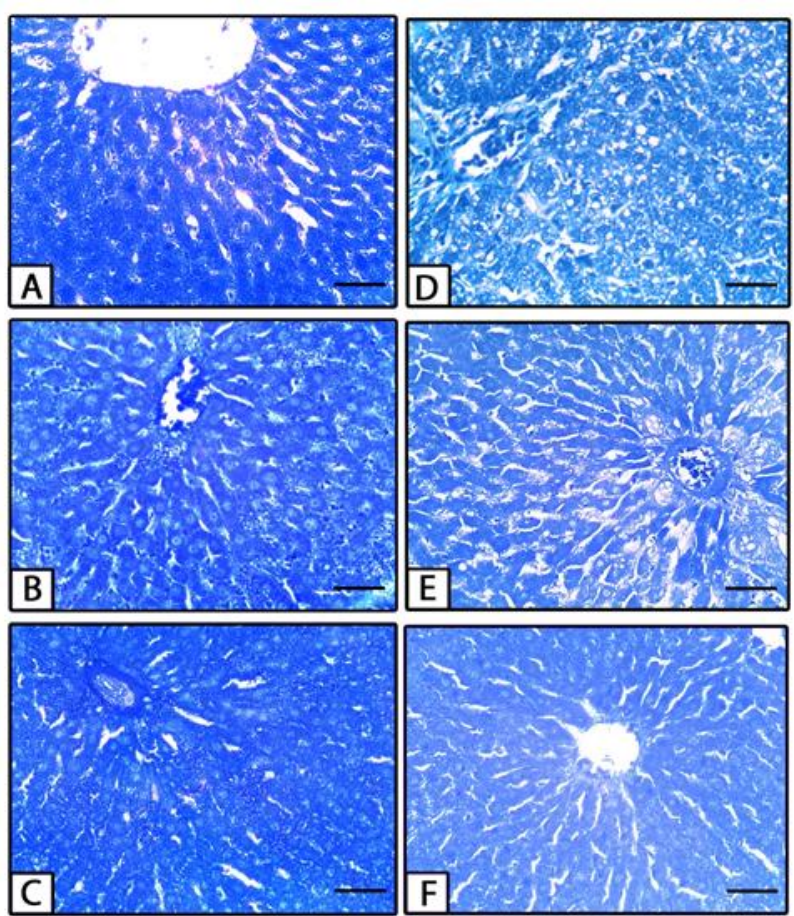

Fig (5): Liver histochemical demonstration for total protein of STZ and/or saffron and fenugreek -treated rats. Liver section of control rats (A) showing normal content and localization in all hepatocytes, liver sections of saffron (B) and fenugreek (C) -treated rats illustrating normal distribution and content as in control group, liver section of STZ treated rats (D) displaying reduced protein contents and cytoplasmic vacuolization in the hepatocytes, liver section of saffron + STZ treated rats (E) showing some of the hepatocytes with reduction in protein content and cytoplasmic vacuolization and others showed restoration of proteins content, liver section of fenugreek + STZ -treated rats (F) illustrating normal distribution and content of protein materials in all most of hepatocytes (Bromophenol blue stain, scale bar $=50 \mu \mathrm{m}$ )

treated animals showed reduction in the proteins contents and cytoplasmic vacuolization in the hepatocytes near or around the central vein. However, in other foci, restoration of proteins materials was observed in other hepatocytes (Fig 5E). Examination of liver sections of fenugreek + STZ treated animals revealed normal content and distribution of proteins materials all over the hepatocytes as in the control group (Fig 5F).

\section{Ultrastructural observations.}

In electron microscope preparations, the hepatic cells from the control group showed normal rounded nucleus with electron-Lucent euchromatin and scattered areas of heterochromatin (Fig 6A). The cytoplasm showed a granular appearance there were numerous rounded and elongated mitochondrial profiles with electron-dense matrix. Also, there were profiles of rough endoplasmic reticulum between the mitochondria (Figs 6A\&6B). The bile canaliculi were wide channels formed by opposing hepatic cells. 

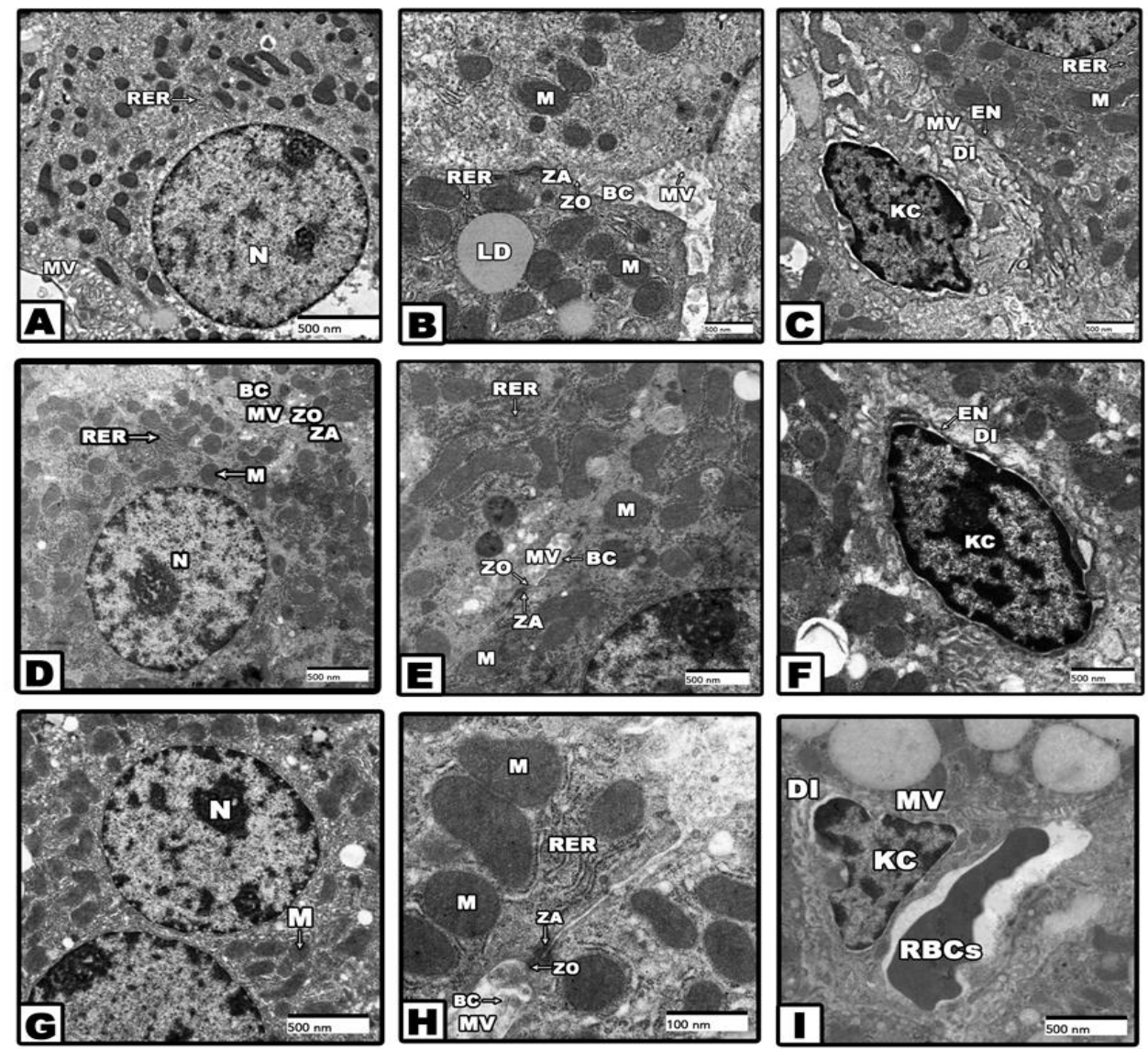

Fig (6): Electron micrographs of liver section of control rats (A,B\&C), saffron (D,E \&F) and fenugreek (G,H\&I) treated rats showing normal hepatocytes, bile canaliculi and blood sinusoids. Abbreviations; nucleus (N), mitochondria (M) , rough endoplasmic reticulum ( RER), space of Disse (DI), endothelial cells (EN), Zonula occludents (ZO) , Zonula adherens (ZA), bile canaliculi (BC), microvilli (MV), lipid droplets (LD), Kupffer cells (KC) and red blood cells (RBCs).

Microvilli of the hepatic cell were found to project The structure of the hepatic cells, bile canaliculi and into the lumen of the bile canaliculus, and junctional blood sinusoids of both saffron and fenugreek treated complex secured the attachment of the hepatic cells rats were found to be quite normal as those of the around these canaliculi (Fig 6B). The plasma control animals (Figs 6D-6I).

membrane of the hepatic cells facing the blood sinusoids was formed of microvilli which was called space of Disse. The hepatic sinusoids were lined by an extremely thin walled discontinuous layer of in endothelial and Kupffer cells. The endothelial cells were extremely thin with an electron-lucent cytoplasm. A large Kupffer cells were macrophage lining the sinusoids (Fig 6C).

Electron microscopic examination of the liver tissue of STZ - diabetic rats showed major alteration in the structural integrity of the intracellular organelles with disintegeral or dissolution of the cytoplasm. Also, numerous lipid droplets of variable size were observed within the hepatocytes (Figs 7A\&7C). The rough endoplasmic reticulum was ill- 

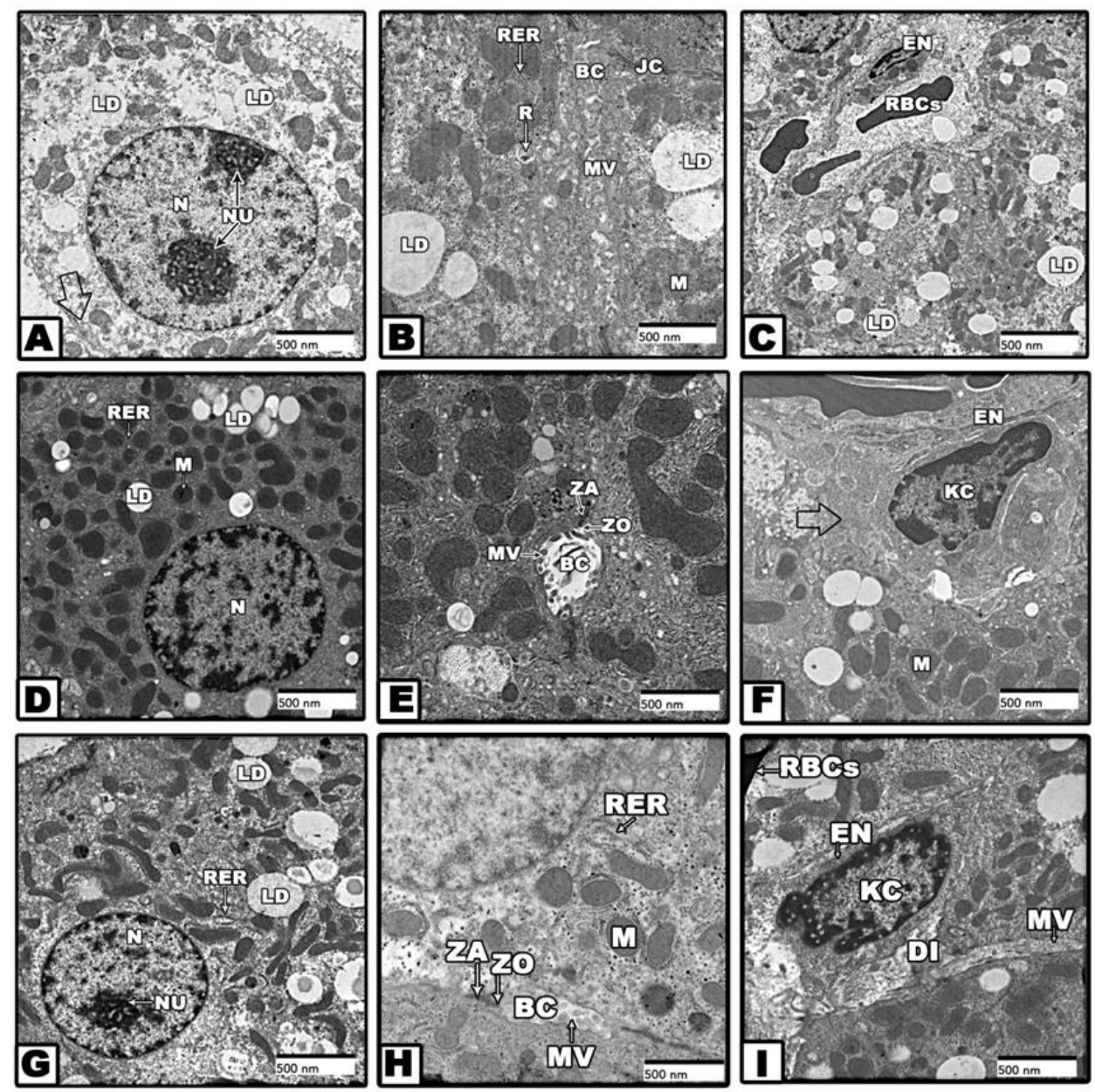

Fig (7): Electron micrograph of liver section of STZ treated rats (A\& B \& C) showing the presence of the nucleus (N) with two nucleoli $(\mathrm{Nu})$, mitochondria $(\mathrm{M})$ with electron-lucent matrix, lipid droplets (LD) and disintegration of the cytoplasm (arrow heads) with ill-defined RER,dilated bile canaliculi (BC), broken and detached endothelial cells (EN), RBCs infiltration between the hepatocytes and distenstion of the blood sinusoids with proteinaceous material. liver section of both saffron+ STZ treated rats (D\&E\&F) and fenugreek + STZ treated rats (G\&H\&I) displaying an improvement in the hepatocytes, bile canaliculi and blood sinusoids structure. Abbreviations; nucleus $(\mathrm{N})$, electron-dense mitochondria $(\mathrm{M})$, rough endoplasmic reticulum (RER), narrow space of Disse (arrow heads), endothelial cells (EN), Zonula occludents (ZO), Zonula adherens (ZA), bile canaliculi (BC), microvilli (MV), lipid droplets (LD), Kupffer cells (KC) and red blood cells (RBCs).

defined as compared to that of the control group and some of them showed detachment of ribosomes in the cytoplasm (Fig 7B). Altered mitochondria with electron-lucent matrix and intercristal swelling were also noticed (Fig 7B). Dilated bile canaliculi with a plenty of pleomorphic microvilli were observed. However, the blood sinusoids appeared broken with detachment of the endothelial cells and infiltration of RBCs between the hepatocytes (Fig 7C).

In Saffron+ STZ treated diabetic group, there was an apparent decrease in hepatocytes degeneration and the nucleus appeared normal (Fig 7D). Profiles of rough endoplasmic reticulum around the electrondense mitochondria were observed. However some of the mitochondria in the group still suffer from intercristae swelling. Also, an obvious decrease in the lipid droplets in the cytoplasm was noticed (Figs 7D \&7E). The bile canaliculi with aplenty of pleomorphic microvilli were observed (Fig 7E). On the other hand the blood sinusoids with Kupffer and endothelial cells and narrow space of Disse was noticed (Fig 7F). 
Preadministration of fenugreek to STZ treated diabetic rats restored most of the liver ultrastructure changes. The liver tissue of this group showed rounded nucleus with normal distribution of chromatin materials and prominent nucleolus. Also, profiles of normal mitochondria and cisternae of RER were observed in the cytoplasm (Fig 7G). Moreover the bile canaliculi and the blood sinusoids seemed to be normal with respect to that of the control group (Figs 7H\&7I).

\section{Discussion}

Diabetes mellitus is metabolic disorder occurs due to human genetically susceptibility, resulting from defect in insulin secretion, insulin action or both (Kumar et al., 2013). Many traditional herbs are being used by diabetic patients to control the disease (Yaheya, 2009). Nonetheless very few studies are preformed to investigate the efficacy of these herbs clinically. There have been growing interests in the application of natural components as antidiabetic agents (Srinath et al., 2011).

In the present study, the STZ-treated rats showed a significantly increase of plasma glucose level and decrease of plasma insulin level compared to that of control animals. Also, pancreas section of STZ-treated group showed degenerative changes in islets of langerhans, homogenization of the center and apparent relative reduction of the size and number of islets. STZ is a cytotoxic compound obtained from the soil microbes Streptomyces achromogenes. STZ produces oxygen radicals in the body, which cause pancreatic injury and could be responsible for increased blood glucose in animals (Kumar et al., 2012; 2013). In this study, animals treated with Saffron+ STZ or fenugreek+ STZ remarkably attenuated the change in blood sugar, serum insulin levels and improved the pancreatic islet cells structure. Little and Sacks (2009) and Kianbakht and Hajiaghaee (2011) found that saffron, crocin and safranal showed antihyperglycemic and antihypoinsulinemic effects on diabetic rats. The hypoglycemic effect of saffron extract seems to be due to insulin resistance reducing stimulating of glucose uptake by peripheral tissues, and inhibition of intestinal glucose absorption (Youn et al., 2004 and $\mathrm{Xi}$ et al., 2007). However, the activities of fenugreek seeds may be have triggered the beta cells to increase insulin production which promotes glucose uptake and utilization by other tissues (Abd elaziz, 2011 and Hamden et al., 2013). Broca et al. (1999) demonstrated evidences of insulinotropic and antidiabetic properties of 4 hydroxyisoleucine isolated from fenugreek seeds in glucose dependent manner. They suggested that antidiabetic effect of 4 hydroxy isoleucine was, at least in part, from direct pancreatic beta cell stimulation. In addition, fenugreek seed contains $45-60 \%$ carbohydrate, mainly mucilaginous fiber (galactomannans) which reduce the rate of glucose absorption and may also delay gastric emptying, thereby preventing the rise in blood sugar levels following a meal (Gupta et al., 2001). Moreover, fenugreek may exert its antidiabetic effect thought its alkaloids content by modulation of insulin secretion (Abou El-Soud et al., 2007 and Abd elaziz, 2011).

In the present study STZ-treated rats exhibited abnormal metabolic pattern, characterized by increased total lipid, total cholesterol, triglycerides in serum and liver tissue, increased serum LDL-c, v LDL-c and reduced serum HDL-c. In diabetic state lipoprotein lipase is not activated due to insulin deficiency resulting in hypertriglyceridemia and hypercholestermia (Sharma et al., 2003). The preadministration of diabetic rats with saffron extract or fenugreek recorded a significant improvement in the total lipid, total cholesterol, triglycerides in serum and liver tissue, increased serum LDL-c, v LDL-c and HDL-c. He et al. (2005) and Sheng et al. (2006) indicated that crocin has a potent hypotriglyceridemic and hypocholesterolemic activity. The hypolipidemic effects of saffron extract and its constituents may be due to its inhibitory effects on oxygen free radical, MDA levels and intracellular ca concentration in endothelial cell and activating superoxide dismutase (Xiang et al., 2006). Also its inhibitory effect on pancreatic lipase may be another mechanism which may act by reducing the absorption of fat and cholesterol (Sheng et al., 2006). Meanwhile the hypocholesterolemic effect of $T$. Foenum greacum seeds could be attributed to saponin content of the seeds or interference with cholesterol biosynthesis in the liver (Petit et al., 1995; Abd elaziz, 2011 and Rajarajeswari et al., 2012). The amino acid 4 hydroxyisoleucine present in fenugreek may also decrease the plasma triglyceride level (Sharma, 1986). Moreover, the lipids lowering effect of fenugreek might also be attributed to its estrogenic constituent, indirectly increasing thyroid hormone T4 (Mitra et al., 1995 and Abd elaziz, 2011).

Biochemical and histochemical results in the present study of STZ induced diabetic rats showed significant decrease in the total protein and albumin content. This decrease can be attributed to increase protein catabolism and the low serum albumin levels 
of the diabetic animals could be attributed to impaired renal disturbance or impaired liver function for these rats (Iroaganachi et al., 2015). The pre-administration of diabetic rats either with saffron extract or fenugreek showed significant improvement in the total protein and albumin contents when compared with diabetic rats. These results may be due to their antidiabetic role which improved pancreatic $\beta$ cells and increased serum insulin level which has anabolic effect in protein (Abou El-Soud et al., 2007; Arasteh et al., 2010 and Elgazar et al., 2013).

Several workers have reported that STZ-induced diabetes mellitus and association between specific diabetic complications and disturbances in various tissues, such as diabetic nephropathy and cardiovascular diseases, but only limited data is available on the possible association between diabetic complications and liver function (Arkkila et al., 2001; Zafar et al., 2009). Liver is one of the most important organs that maintain blood glucose levels within normal limits thus enhancement of blood sugar yield to imbalance of oxidation-reduction reactions in hepatocytes (Waer and Helmy, 2012). The present study showed that the aminotransferases (AST and ALT) levels were significantly increased in the liver of STZ-treated animals. Elevated activities of serum aminotransferases are a common sign of liver diseases and are observed more frequently among people with diabetes than in general population (Arkkila et al., 2001).

Oxidation stress plays a key role in the pathogenesis of chronic diseases such as diabetes and diabetic complications (Liu et al., 2012 and Tamaddonfard et al., 2013). In this study there is significant decrease in GSH content and significant increase in MDA content and $\mathrm{H}_{2} \mathrm{O}_{2}$ level in the liver tissues of diabetic rats. The data of the present study also revealed that pretreatment of diabetic rats either with saffron extract or fenugreek markedly improves the antioxidant status of liver tissue as GSH level significantly increased and MDA level and $\mathrm{H}_{2} \mathrm{O}_{2}$ level markedly decreased. Assimopoulou et al. (2005); Kanakis et al. (2007) and Chen et al. (2008) and Tamaddonfard et al. (2013) reported that saffron and its active constituent's crocin and crocetin are effective in quenching free radicals and have antioxidant properties. On the other hand, other studies revealed the antioxidant activity of fenugreek seeds and ought this activity partly to the presence of flavonoids and polyphenols (Jayadev et al., 2001 and Annida and Stanely, 2005).
In the present histological and ultrastructural study, STZ-treated animals displayed alteration in the structural integrity of the hepatocytes and their intracellular organelles. The hepatocytes showed marked cytoplasmic vacuolation with pyknotic and karyolitic nuclei. Numerous lipid droplets of variable size, ill-defined rough endoplasmic reticulum and altered mitochondria were observed within the hepatocytes. Moreover, the blood sinusoid appeared broken with detachment of the endothelial cells and infiltration of RBCs between the hepatocytes. Slater (1984) reported that the endoplasmic reticulum is particularly liable to the free radical attack, not only because it is considered as a site of radical production but also due to the enrichment of its membrane with polyunsaturated fatty acids which are susceptible to free radical attack. Such results are in agreement with Damjanov (2000) who stated that, the damage of RER leads to a decrease in protein synthesis as observed in the present biochemical and histochemical findings. In addition, the numerous lipid droplets observed in the cytoplasm of the hepatocytes of the present study may be attributed to impaired protein synthesis as a result of RER damage, and accordingly inhibition of hepatic lipoprotein manufacture which leads to release of the lipids and its accumulation in the liver hepatocytes (Ganong, 1995; Ohno et al., 2000 and Zafar et al., 2009). Also, Powell et al. (2007) and khalil et al. (2010) declared that diabetes is one of the metabolic causes of steatosis. Moreover, liver sections of STZ-induced diabetic animals illustrated an increase in the amount of collagen fibers around the central vein. Sricharoenvej et al. (2012) and Madhankumar (2016) attributed this finding to the activation of hepatic stellate cells. The accumulation of numerous collagen fibers may lead to more advanced and severe liver injury (Iredale, 2003 and Friedman, 2008). Also, oxidation stress in particular lipid peroxidation induces collagen synthesis (Muriel and Moreno, 2004) as demonstrated in the present study. In diabetes, hyperglycemia causes increased oxygen free radicals from glucose oxidation and protein glycosylation (Tesfamariam, 1994 and $\mathrm{Al}$ Shaikh, 2010). Therefore, the dramatic histological and ultrastructural alternation observed in the present study may be attributed to increased oxidation stress.

The present study showed the administration with saffron extract or fenugreek to STZ- treated animals resulted in amelioration in serum and liver ALT and AST activities and improved most of the abnormalities in the liver histological and ultrastructure when compared with diabetic group. The protective effects of saffron extract and fenugreek 
may be related to their active constituents; antioxidant properties and its effect in reducing blood glucose level and radical scavenging role (Cam et al., 2003; Mohammad et al., 2011; Elgazar et al., 2013 and Das, 2014).

Histochemically, the current work showed weak PAS positive reaction in liver sections of STZ- treated animals indicating marked decrease in the glycogen content in the hepatocytes and this result was confirmed biochemically, corroborating Welt et al. (2004), Khalaf and Abdel Gabbar (2008) and Onaolapo and Onaolapo (2012) who suggest that in the diabetic individuals, the synthesis and the action of glycogenolytic and glycogenic enzymes would be impaired, which would decrease or prevent the synthesis of glycogen or increase in its breakdown in the liver. However, liver sections of fenugreek + STZ treated animals showed an increase in the polysaccharides content and this may be attributed to the decreased activity of gluconeogenic enzymes (Abd elaziz, 2011).

In conclusion, the present study showed that STZ-induced diabetes impaired liver structure and function and confirmed that saffron extract and fenugreek supplementation were able to attenuate these effects through its hypoglycemic and antioxidant properties. Therefore, the present study provides a scientific rationale for the use of saffron extract and fenugreek supplementation as antidiabetic and hepatoprotective agents.

\section{References}

Abd elaziz, E.A. (2011). 'Pathological and biochemical studies on the effect of Trigonella foenum Graecum and Lupinus termis in alloxan induced diabetic rats', World Applied Sciences Journal, 12 (10): 1839-1850.

Abe, K. and Saito, H. (2000). 'Effects of saffron extract and its constituent crocin on learning behaviour and long-term potentiation', Phytotherapy Research, 14: 149152.

Abou El-Soud, N.H.; Khalil, M.Y.; Hussein, J.S.; Oraby, F.S.H. and Farrag, A.R.H. (2007). 'Antidiabetic effect of fenugreek alkaloid extract in streptozotocininduced hyperglycemic rats', Journal of Applied Sciences Resesrch, 3(10): 1073-1083.

Aebi, H.E. (1984). 'Catalases In: Methods of enzymatic analysis‘, Vol 3 (Bergmeyer HU, Bergmeyer J, Grassi M, eds) Verlag Chemie , pp 273-286.

AL-Shaikh, M.N. (2010). 'Histological and Histochemical changes in diabetic male rat liver and intestine: and protective effect of cinnamon oil', Journal of the Faculty of Medicine, Baghdad, 52(3): 366-371

Amin, A.; Alkaabi, A.; Al-Falasi, S.; Daoud, S.A.
(2005). 'Chemopreventive activities of Trigonella foenum graecum (fenugreek) against breast cancer', Cell Biology International, 29:687-694.

Annida, B. and Stanely, P. (2005). 'Supplementation of fenugreek leaves reduces oxidative stress in streptozotocin-induced diabetic rats', Journal of Medicinal Food, 8: 382-385.

Arasteh, A.; Aliyev, A.; Khamnei, S.; Delazar, A.; Mesgari, M. and Mehmannavaz, Y. (2010). 'Effects of hydromethanolic extract of saffron (Crocus sativus) on serum glucose, insulin and cholesterol levels in healthy male rats', Journal of Medicinal Plants Research, 4: 397402.

Arkkila, P.E.; Koskinen, P.J.; Kantola, I.M.; Ronnemaa, T.; Seppanen, E. and Viikari, J.S. (2001). 'Diabetic complications are associated with liver enzyme activities in people with type-1 diabetes', Diabetes Research and Clinical Practice, 52(2):113- 118.

Arunachalam, K. and Parimelazhagan, T. (2014). 'Antidiabetic and enzymatic antioxidant properties from methanol extract of Ficus talboti bark on diabetic rats induced by streptozotocin', Asian Pacific Journal of Reproduction, 3(2): 97-105.

Assimopoulou, A.N.; Sinakos, Z.; Papageorgiou, V.P. (2005). 'Radical scavenging activity of Crocus sativus L. extract and its bioactive constituents', Phytotherapy Research, 19: 997-1000.

Azaizeh, H.; Saad, B.; Khalid, K. and Said, O. (2006). 'The State of the art of traditional arab herbal medicine in the eastern region of the mediterranean', Evidence-Based Complementary and Alternative Medicine, 3:229-235.

Basch, E.; Ulbricht, C.; Kuo, G.; Szapary, P. and Smith, M. (2003). 'Therapeutic applications of fenugreek', Alternative Medicine Review, 8: 20-27.

Bathaie, S.Z. and Mousavi, S.Z. (2010). 'New applications and mechanisms of action of saffron and its important ingredients', Critical Reviews in Food Science and Nutrition, 50: 761-786.

Billaud, C. and Adrian, J. (2001). 'Fenugreek: composition, nutritional value and physiological properties', Sciences des Aliments, 21: 3-26.

Broca, C.; Gross, R.; Petit, P.; Sauvaire, Y.; Manteghetti, M. and Tournier, M. (1999). '4Hydroxyisoleucine: experimental evidence of its insulinotropic and antidiabetic properties', American Journal of Physiology, 277: 617-23.

Cam, M.O.; Yavuz, A.; Guven, F.; Ercan, N.; Bukan, and Ustundag, N. (2003). 'Protective effects of chronic melatonin treatment against renal injury in streptozotocin-induced diabetic rats', Journal of Pineal Research, 35: 212-220.

Chen, Y.; Zhang, H.; Tian, X.; Zhao, C.; Cai, L.; Liu, Y.; Jia, L.; Yin, H.-X. and Chen, C. (2008). 'Antioxidant potential of crocins and ethanol extracts of Gardenia jasminoides ELLIS and Crocus sativus L.: A relationship investigation between antioxidant activity and crocin contents', Food Chemistry, 109: 484-492.

Chermahini, H.S.; Abd Majid, F. A.; Sarmidi, M. 
R.; Taghizadeh, E.; Salehnezhad, S. (2010). 'Impact of mechanisms',Life Sciences, 77: 907-921. saffron as an anti-cancer and anti-tumor herb', African Journal of Pharmacy and Pharmacology, 4(11):834-840.

Iredale, J.P. (2003). 'Cirrhosis: new research Cowan, M.M.; (1999). 'Plant products as antimicrobial agents', Clinical Microbiology Reviews, 12:564-582.

Damjanov I. (2000).'Pathology for the healthrelated professions', 2ed. W.B.Saunders Company.

Das, S. (2014). ' Hepatoprotective activity of methanol extract of fenugreek seeds on rats', International Journal of Pharmaceutical Sciences and Research, 5:15061513.

Doumas, B.; Waston, W. and Biggs, H. (1971). 'Albumin standards and measurements of serum albumin with bromocresol green', Clinica Chimica Acta, 31:87.

Elgazar, A. F.; Rezq, A. A. and Bukhari, H. M. (2013). 'Anti-hyperglycemic effect of saffron extract in alloxan-induced diabetic rats', European Journal of Biological Sciences, 5 (1): 14-22.

Evans, J. L. (2007). 'Antioxidants: do they have a role in the treatment of insulin resistance? ', The Indian Journal of Medical Research ,125:355-372.

Flier, J. S.; Kahn, C. R.; Jarrett, D. B. and Roth, J. (1976). 'Characterization of antibodies to the insulin receptor: a cause of insulin-resistant diabetes in man", Journal of Clinical Investigations, 58, 1442-1449.

Friedewald, W. T.; Levy, R. I. and Fredrickson, D. S. (1972). 'Estimation of the concentration of low-density lipoprotein cholesterol in plasma, without use of the preparative ultracentrifuge', Clinical Chemistry, 18:499502.

Friedman, S. L. (2008). 'Hepatic stellate cells: protean, multifunctional, and enigmatic cells of the liver', Physiological Reviews, 88(1): 125-172

Frings, C. S.; Fendley, T. W.; Dunn, R. T. and Queen, C. A. (1972). 'Improved determination of total serum lipids by sulphophosphovanillin reaction', Clinical Chemistry, 18: 673-674.

Ganong,WF. (1995). 'Review of medical physiology‘, 17th ed. Appleton and Lange California.

Gupta, A.; Gupta, R. and Lal, B. (2001). 'Effect of Trigonella foenum graecum seeds on glucaemic control and insulin resistance in type 2 diabetes mellitus', Journal of the Association of Physicians of India, 49: 1057-1061.

Hamden, K.; Mnafgui, K.; Amri, Z.; Aloulou, A. and Elfeki, A. (2013). 'Inhibition of key digestive enzymes related to diabetes and hyperlipidemia and protection of liver-kidney functions by trigonelline in diabetic rats', Scientia Pharmaceutica, 81: 233-246

Heeba, G. H. and Abd-Elghany, M. I. (2010). 'Effect of combined administration of ginger (Zingiber officinale Roscoe) and atorvastatin on the liver of rats', Phytomedicine, 17:1076-1081.

Henry, R. J. (1964). 'Principles and Technics Ed', Harper \& Row, New york- Chap.II: Proteinsa Determination on protein by the burit reaction: 182-188.

He, S.Y.; Qian, Z.Y.; Tang, F.T; Wen, N.; Xu, G.L. and Sheng, L. (2005). 'Effect of crocin on experimental atherosclerosis in quails and its

provides a basis for rational and targeted treatments', British Medical Journal, 327(7407): 143-147.

Iroaganachi, C.; Eleazu, O.; Okafor, P.N. and Nwaohu, N. (2015). 'Effect of unripe plantain (musa paradisiaca) and ginger (Zingiber officinale) on blood glucose, body weight and feed intake of streptozotocininduced diabetic rats', Journal of Biochemistry, 9: 1-6.

Jayadev, R.; Dhananjay, G.; Araga, R.; Pramod, K.; Yadava, Z. and Baquer, N. (2001). 'Trigonella foenum graecum (fenugreek) seed powder improves glucose homeostasis in alloxan diabetic rat tissues by reversing the altered glycolytic, gluconeogenic and lipogenic enzymes',Molecular and Cellular Biochemistry, 224: 45-51.

Kanakis, C. D.; Tarantilis, P. A.; Tajmir-Riahi, H.

A. and Polissiou, M. G. (2007). 'Crocetin, dimethylcrocetin and safranal bind human serum albumin: stability and antioxidative properties',Journal of Agricultural and Food Chemistry, 55:970-977.

Kassaian, N.; Azadbakht, L; Forghani, B and Amini, M. (2009). 'Effect of fenugreek seeds on blood glucose and lipid profiles in type 2 diabetic patients', International Journal for Vitamin and Nutrition Research, 79(1): 34-39.

Kataria, D.; Kumar, C.; Nerkar, N.; Gadiya. R. V. and Abhyankar, M. M. (2011). 'Detail profile of Crocus sativus', International Journal of Pharma and BioSciences, 2: $530-540$.

Khalaf, G. and Abdel-Gabbar, M. (2008). ' Effect of barley (Hordeum Vulgare) on the liver of diabetic rats: histological and biochemical study', The Egyptian Journal of Histology, 31(2), 245-255.

Khalil, M.; Mohamed, G.; Dallak, M.; Al-Hashem, F.; Sakr, H.; Eid ,R.A; Adly, M. A.; Al-Khateeb,M.; Banihani, S.; Hassan, Z. and Bashir, N.(2010). 'The effect of Citrullus colocynthis pulp extract on the liver of diabetic rats a light and scanning electron microscopic study', American Journal of Biochemistry and Biotechnology, 6(3): 155-163.

Kianbakht, S. and Hajiaghaee, R. (2011). 'Antihyperglycemic effects of saffron and its active constituents, crocin and safranal, in alloxan induced diabetic rats', Journal of Medicinal Plants, 10: 39-43.

Kumar, B. S. A.; Lakshman, K.; Jayaveea, K. N.; Shekar, D. S.; Khan, S.; Thippeswamy, B. S. and Veerapur, V. P. (2012). 'Antidiabetic, antihyperlipidemic and antioxidant activities of methanolic extract of Amaranthus viridis Linn in alloxan induced diabetic rats', Experimental and Toxicologic Pathology, 64:75-79.

Kumar, V.; Ahmed, D.; Verma, A.; Anwar, F.; Ali, M. and Mujeeb, M. (2013). 'Umbelliferone beta-Dgalactopyranoside from Aegle marmelos (L.) corr. an ethnomedicinal plant with antidiabetic, antihyperlipidemic and antioxidative activity', BioMed Central Complementary and Alternative Medicine, 13:273.

Liakopoulou-Kyriakides, M. and Kyriakidis, D. (2002). 'Crocus sativus-biological active constituents', Studies in Natural Products Chemistry, 26: 293-312. 
Little, R.R. and Sacks, D .B (2009). 'HbA1c: how do we measure it and what does it mean? 'Current Opinion in Endocrinology, Diabetes and Obesity, 16: 113 -118.

Liu, Z.; Stanojevic, V.; Brindamour, L.J.and Habener, J.F. (2012). 'GLP1-derived nonapeptide GLP1(28-36)amide protects pancreatic beta-cells from glucolipotoxicity', Journal of Endocrinology, 213:143-154.

Madhankumar, S. J. (2016). 'Protective effect of Cynodon dactylon aqueous extract in streptozotocin diabetes induced liver damage in rats: Histological Study', International Journal of Pharmaceutical and Clinical Research, 8(2): 137-141.

Masson PJ.(1929). 'AFIP modification', J Tech Methods , 12: 75-90.

MeCleary, B. V. and Codd, R. (1991). 'Measurement of (1-.3.1-.4)-]3-Dglucan in barley and oats: a streamlined enzymatic procedure', Journal of the Science of Food and Agriculture, 55:303-312.

Mazia, D.; Brewer; P. A.; Alfert, M. (1953). 'The cytochemical staining and measurement of protein with mercuric bromophenol blue', Biological Bulletin, 104: 5767.

Miraldi, E.; Ferri, S. and Mostaghimi, V. (2001). 'Botanical drugs and preparations in the traditional medicine of West Azerbaijan (Iran)', Journal of Ethnopharmacology, 75:77-87.

Mitra, A. and Bhattacharya, D. (2006). 'Dosedependent effects of fenugreek composite in diabetes with dislipidaemia', Internet Journal of Food Safety, 8: 49-55.

Mitra, S. K.; Gopumadhavan, S.; Muralidhar, T. S.; Anturlikar, S. D. and Sujatha, M. B. (1995). 'Effect of D400 , a herbomineral preparation on lipid profile, glycated hemoglobin and glucose tolerance in streptozotocin induced diabetes in rats', Indian Journal of Experimental Biology, 33: 798-800.

Mohammed, R.; Daryoush, M.; Ali, R.; Yousef, D. and Mehrdad, N. (2011). 'Attenuation of oxidative stress of hepatic tissue by ethanolic extract of saffron (dried stigmas of Crocus sativus L.) in streptozotocin (STZ)-induced diabetic rats', African Journal of Pharmacy and Pharmacology, 5(19): 2166-2173.

Montero, A.; Munger, K.; Khan, R.; Valdivielso, J.; Morrow, J.; Guasch, A; Ziyadeh, F. and Badr, K. (2000). ' $F$ (2)-isoprostanes mediate high glucose-induced TGF-beta synthesis and glomerular proteinuria in experimental type I diabetes', Kidney International, 58: 1963-1972.

Muriel, P. and Moreno, M. (2004). 'Effects of silymarin and vitamins $\mathrm{E}$ and $\mathrm{C}$ on liver damage induced by prolonged biliary obstruction in the rat', Basic Clinical Pharmacology Toxicology, 94: 99-104.

Nandini, C. D.; Sambaiah, K. and Salimath, P. V. (2000). 'Effect of dietary fibre on intestinal and renal disaccharidases in diabetic rats', Nutrition Research, 20(8):1301-1307.

Ohkawa, H.; Ohishi, N. and Yagi, K. (1979). 'Assay for lipid peroxidation in animal tissues by thiobarbituric acid reaction', Annals of Biochemistry, 95, 351- 358.

Ohno, T.; Horio, F.; Tanaka, S.; Terada, M. and
Namikawa, T. (2000). 'Fatty liver and hyperlipidemia in IDDM (insulin-dependent diabetes mellitus) of streptozotocin-treated shrews ‘, Life Science, 66: 125-131.

Onaolapo, A.Y. and Onaolapo, O.J. (2012).

'Ocimum Gratissimum Linn causes dose dependent hepatotoxicity in streptozotocin-induced diabetic wistar rats', Macedonian Journal of Medical Sciences, 5(1):17-25. Oyedemi, S.O.; Adewusi, E.A.; Aiyegoro, O. A. and Akinpelu, D.A. (2011). 'Antidiabetic and haematological effect of aqueous extract of stem bark of Afzelia africana (Smith) on streptozotocin-induced diabetic Wistar rats', Asian Pacific Journal of Tropical Biomedicine, 1(5):353-58.

Pearse AGE. (1985). Histochemistry, Theoretical and Applied, 4th ed.; Vol. 2, Churchill, Ltd.: London.

Petit, P. R.; Sauvaire, Y. D.; Hillaire-Buys, D. M.; Leconte, O. M.; Baissac, Y. G.; Ponsin, G. R. and Ribes, G. R. (1995). 'Steroid saponins from fenugreek seeds: extraction, purification, and pharmacological investigation on feeding behavior and plasma cholesterol', Steroids, 60: 674-680.

Powell, C. K.; Hill, E. G. and Clancy, D. E. (2007). 'The Relationship between health literacy and diabetes knowledge and readiness to take health actions ${ }^{6}$, Diabetes Educator, 33: 144-151.

Premkumar, K.; Abraham, S. K.; Santhiya, S. T. and Ramesh, A. (2003). 'Inhibitory effects of aqueous crude extract of saffron (Crocus sativus L.) on chemicalinduced genotoxicity in mice', Asia Pacific Journal of Clinical Nutrition, 12 (4):474-476.

Prins, H. K. and Loose, J. A. (1969). 'Glutathione "Chapter 4" In: Yunis JJ, editor. 'Biochemical Methods in Red Cell Genetics', London: Academic Press, 126-129.

Puri, D.; Prabhu, K. M. and Murthy, P. S. (2012). 'Antidiabetic effect of Gll compound purified from fenugreek (Trigonella foenum-graecum Linn) seeds in diabetic rabbits ', Indian Journal of Clinical Biochemistry, 27: 21-27.

Rahimi, R.; Nikfar, S.; Larijani, B. and Abdollahi, M. (2005). 'A review on the role of antioxidants in the management of diabetes and its complications', Biomedicine \& Pharmacotherapy, 59: 365-373.

Rajarajeswari, A.; Vijayalakshmi, P. and Sadiq, M. (2012). 'Influence of Trigonella Foenum graecum (fenugreek) in alloxan induced diabetic rats', The Bioscan, 7(3): 395-400.

Razavi, M.; Hosseinzadeh, H.; Abnous, K.; Motamedshariaty, V. S. and Imenshahidi, M. (2013). 'Crocin restores hypotensive effect of subchronic administration of diazinon in rats', Iranian Journal of Basic Medical Sciences, 16 (1): 64.

Reitman, S. and Frankel, S. (1957). 'A method of assaying liver enzymes in human serum', American Journal of Clinical Pathology, 28: 56- 58.

Reynolds, E.S. (1963). 'The use of lead citrate at high $\mathrm{pH}$ as an electron microscopy،, Journal of Cell Biology, 17: 208-212.

Schmidt, M.; Betti, G. and Hensel, A. (2007). 'Saffron in phytotherapy: pharmacology and clinical uses', 
Wiener Medizinische Wochenschrift, 157:315-319.

Sharma, R. D. (1986). 'Effect of fenugreek seeds and leaves on blood glucose and serum insulin responses in human subjects', Nutrition Research, 6: 1353-1364.

Sharma, S.; Nasir, A.; Parbhu, K.; Mursy, B. and Dev, G. (2003). ' Hypoglycemic and hypolipidemic effect of etanolic extract of seeds in alloxan induced diabetic rabbits', Journal Ethnopharmacol, 85: 201.

Sheng, L.; Qian, Z.; Zheng, S. and Xi, L. (2006). 'Mechanism of hypolipidemic effect of crocin in rats: crocin inhibits pancreatic lipase', European Journal of Pharmacology, 543(1-3): 116-122.

Slater, T.F. (1984). 'Free radical mechanism in tissue injury‘, Biochemical Journal, 222: 1-15.

Sivajothi, V.; Dey, A.; Jayakar, B. and Rajkapoor, B. (2007). 'Antihyperglycemic property of Tragiacannabma in streptozotocin-induced diabetic rats', Journal of Medicinal Food, 10 (2): 361-365.

Sricharoenvej, S.; Siratechawiwat, A.; Lanula, P.; Niyomchan, A. and Baimal, S. (2012). 'Ultrastructural changes of hepatic stellate cells in streptozotocin- induced diabetic rats', Siriraj Medical Journal, 64 (1): 45-48.

Srinath, K. R.; Chowdary, P.; Palanisamy, P., Vamsy, K.; Aparna, S. and Ali, S. (2011). 'Formulation and evaluation of effervescent tablets of paracetamol, 'International Journal of Pharmaceutical Research and Development, 2(12):76-104.

Srivastava, R.; Ahmed, H. and Dixit, R. K. (2010). 'Crocus sativus L.: a comprehensive review', Pharmacognosy Reviews,4: 200-208.

Tamaddonfard, E.; Farshid, A.A.; Asri-Rezaee, S.; Javadi, S.; Khosravi, V.; Rahman, B. and Mirfakhraee, Z. (2013). 'Crocin improved learning and memory impairments in streptozotocin-induced diabetic rats', Iranian Journal of Basic Medical Sciences, 16: 91-100.

Tesfamariam, B. (1994). 'Free radicals in diabetic endothelial cell dysfunction ', Free Radical Biology and Medicine, 16: 383-91.

Ulloa, J. A.; Valencia, M. E. and Garcia, Z. H. (1988). 'Protein concentrate from chickpea: nutritive value of a protein concentrate from chickpea (Cicer arietinum) obtained by ultrafiltration and its potential use in an infant formula', Journal of Food Science, 53: 1396-1398.

Waer, H. F. and Helmy, S. A. (2012). 'Cytological and histochemical studies in rat liver and pancreas during progression of streptozotocin induced diabetes and possible protection of certain natural antioxidants', Journal of Nutrition and Food Sciences, ISSN: 2155-9600 .

Weesner, P.M. (1968): ' General Zoological Microtechniques‘ ,Copyright, Sicientific Book Agency, Calcutta.

Welt, K.; Weiss, J.; Martin, R.; Dettmer, D.; Hermsdorf, T.; Asayama, K.; Meister, S. and Fitzl, G. (2004). 'Ultrastructural, immunohistochemical and biochemical investigations of the rat liver exposed to experimental diabetes und acute hypoxia with and without application of Ginkgo extract', Experimental and Toxicologic Pathology, 55(5):331-345.

WHO (2004). 'Expert Consultation: Appropriate body-mass index for Asian populations and its implications for policy and intervention. Lancet', 363:157-63.

Xiang, M.; Yang, M.; Zhou, C.; Liu, J.; Li, W. and Qian, Z. (2006). 'Crocetin prevents AGEs-induced vascular endothelial cell apoptosis', Pharmacological Research, 54: 268-274.

Xi, L.; Qian, Z.; Shen, X.; Wen, N. and Zhang, Y. (2005). 'Crocetin prevents dexamethasone-induced insulin resistance in rats', Planta Medica, 71: 917-922.

Xi, L.; Qian, Z.; Xu, G.; Zheng, S.; Sun, S.; Wen, N.; Sheng, L.; Shi, Y. and Zhang, Y.(2007). 'Beneficial impact of crocetin, a carotenoid from saffron on insulin sensitivity in fructose-fed rats', Journal of Nutritional Biochemistry, 18: 64-72.

Yaheya, M. M. I. (2009). 'Clinical evaluation of antidiabetic activity of Trigonella seeds and Aegle marmelos Leaves', World Applied Sciences Journal, 7(10): 1231-1234.

Youn, J. Y.; Park, H. Y. and Cho, K. H. (2004). 'Anti hyperglycemic activity of Commelina Communis L. inhibition of a-glucosidase', Diabetes Research and Clinical Practice, 66: 149-155.

Young, D.S. (1995). 'Effects of drugs on Clinical Lab' ,Tests, 4th ed AACC Press.

Zafar, M.; Naqvi, S.N.; Ahmed, M. and Kaimkhani, Z. A. (2009). 'Altered liver morphology and enzymes in streptozotocin-induced diabetic rats', International Journal of Morphology, 27(3):719-25.

Zargari, A. (1993). Medicinal plants. Volume 4, Tehran University Press, Tehran: 574-578. 